\title{
METODOLOGI PENDIDIKAN ISLAM DALAM MENDIDIK ANAK
}

\author{
Oleh: \\ Hasbi Indra \\ Fakultas Agama Islam Universitas Ibn Khaldun Bogor \\ hasbiindra@fai.uika-bogor.ac.id
}

\begin{abstract}
Abstrak
Tulisan ini ingin menemukan bagaimana metodologi pendidikan Islam dalam proses pendidikan anak didik. Anak didik adalah bukan seonggok daging semata, tetapi lebih dari itu ia makhluk Tuhan yang paripura. Hanya saja ketika manusia lahir dan berkembang remaja atau bahkan dewasa baru ia mengenal untuk apa ia hidup. Ia hidup menyandang tugas ke khalifahan yaitu mengelola alam lalu ia mengadari bahwa Ia hidup oleh Sang Pencipta, karena itu harus beribadah kepada-Nya sebagai salah satu rasa syukurnya. Hal-hal itu dapat diperoleh melalui bangku pendidikan.Pendidikan tentu saja melalui proses yang menggunakan metodologi. Metodologi pendidikan Islam tentu saja berbasis norma-norma islam yang memandang bahwa manusia itu diciptakan dalam bentuk sebaik-baiknya. Manusia dalam pandangan Tuhan sama yang membedakannya kerena ketaqwaannya apakah ia masih kecil berusia muda atau sudah dewasa. Di masa kecil ia belum baligh ia masih tidak berdosa, itulah taqwanya, masa remaja ia dapat meraih prediket taqwa melalui upaya yang dilakukannya demikian pula usia dewasanya lebih memiliki kesempapatan untuk meraih posisi taqwa tersebut. Intinya metodologi pendidikan Islam memandang anak didik, manusia yang mulia dan manusia yang memiliki sisi kemanusiaannya.
\end{abstract}

Kata Kunci: metodologi pendidikan, pendidikan anak, pendidikan Islam

\section{Pendahuluan}

Pendidikan Islam saat ini hidup di tengah era globalisasi, berbagai fenomena global telah hadir di hadapannya.Institusi ini telah lama eksis di tanah air.Institusi in berlandaskan pada nilai-nilai Islam yang bersumber Al-quran dan Al-hadits juga ijtihad ilmuan Muslim.Pendidikan Islam memiliki berbagai jenis ada yang disebut dengan pendidikan al-quran, pendidikan pesantren, pendidikan diniyah, pendidikan madrasah dan pendidikan tinggi Islam yang jumlah anak didik dalam kisaran 21 juta lebih. ${ }^{1}$ Pendidikan al-quran, pendidikan pesantren, pendidikan diniyah hampir sepenuhnya diselenggarkan oleh masyarakat, sementara itu pendidikan madrasah dan pendidikan tinggi Islam diselenggarakan oleh pemerintah tetapi ada pula diselenggarakan oleh masyarakat.Pendidikan Islam telah menjadi bagian dari sistem pendidikan nasional yang ikut mencerdaskan anak bangsa. ${ }^{2}$ Pendidikan ini membentuk

\footnotetext{
${ }^{1}$ Ditjen Pendis, Statistik Pendidikan Islam 2012-2013, (Jakarta: Ditjen Pendis, 2014), hal. 1-225

${ }^{2}$ Peraturan Pemerintah No. 55 tahun 2007.
} 
anak didik yang cerdas, berilmu, berwawasan luas untuk ikut serta membangun bangsa meraih kemajuannya.

Pendidikan Islam yang berdasarkan pada Al-quran dan Al-hadits, membentuk seorang manusia.Manusia diciptakan Allah dalam bentuk sebaik-baiknya.Ia diciptakan dari dua perpaduan yakni dari sesuatu yang hina tetapi ia diberikan ruh Allah di dalam dirinya. Manusia makhluk ciptaan Allah bukan makhluk yang ada karena tanpa sebab, ia diciptakan oleh Allah untuk menjadi khalifah di muka bumi serta mengelolanya, puncaknya ia diciptakan untuk mengabdi kepada Sang Khalik. Berbeda dengan pandangan sekularis manusia diciptakan karena proses alam dan hidupnya untuk dirinya sendiri, diri manusia memiliki sifat hedonistik itulah salah satu tujuan hidupnya.

Manusia dalam pandanganIslam dalam bentuk ideal menuju insan kamil. Insan yang paripurna dalam proses kehidupannya, manusia yang paling tahu bersyukur kepada Tuhannya. Manusia yang dituju harus melalui proses pendidikan yang dilalui melalui tahapan atau proses, proses demi prosen dilaluinya. Proses inilah menentukan apakah ia menuju insan yang paripurna. Dalam Al-quran membentuk manusia seperti itu menggunakan kata murabbi, taklim dan ta' $d i b .{ }^{3}$ Intinya manusia harus melalui proses pendidikan yang memanusiakannya. Salah satunya melalui metodologi pendidikan sangat menentukan dalam proses pembentukan manusia. Metodologi pendidikan Islam memandang bahwa anak didik adalah manusia yang mulia yang diciptakan Tuhan untuk bersyukur kepada Sang Pencipta serta untuk mengelola alam yang dianugerahkan untuk kehidupannya.

\section{Pendidikan Islam}

Pendidikan membaca Al-quran biasanya pendidikan awal bagi setiap muslim. Pendidikan ini diselenggarakan di rumah ustadz atau di mushallah atau di masjid, materi pelajarannya membaca Al-quran, dan model pembelajarannya menggunakan talaqqi, santri mengaji Al-quran langsung menghadap sang ustadznya, metode yang digunakan metode Al-baghadi sumber belajarnya langsung ke mushaf Al-quran.Apabila dianggap sudah lancar anak didiknya sang ustadz memindahkan ngajinya ke ayat berikutnya, apabila belum lancar juga santri harus mengulang pada pertemuan berikutnya. Kalau

${ }^{3}$ Syed Muhammad al-Naquib al-Attas, Konsep Pendidikan Dalam Islam, (Bandung: Mizan, 1994), hal. 35-60 
santrinya demikian banyak sang ustadz menunjuk santri senior yang sudah pandai membaca untuk mengajar santri yang lebih yunior. ${ }^{4}$

Pendidikan tersebut bagi santri yang berusia 4 hingga 12 tahun, suatu usia yang sangat strategis dalam pembentuk seseorang. Di pendidikan ini bukan saja dapat membentuk seorang muslim yang fasih membaca Al-quran, berkharakter baik, tetapi juga mempersiapkan pembentukan manusia Indonesia masa depan dalam semua aspek kehidupan.

Seorang kyai bernama Dahlan Zarkasyi di Semarang membuat pembaruan di pendidikan ini melalui Metode Pembelajaran Qiraati dan menerapkannya di Taman pendidikannya tahun 1988 di Semarang. Muncul pula Metode Pembelajaran Iqra' dibuat oleh kyai As'ad Humam di Yogyakarta tahun 1989, juga santri menghapal doadoa yang bersumber dari Al-quran dan Al-hadits, bernyanyi dan menulis indah. Kemudian saat ini berkembang pula metode lain seperti Metode Tilawati, Yanbui, Aldini dan lainnya.Pendidikan ini dikelola secara profesional, ada tenaga kependidikan dan ada tenaga pendidik. Pembelajarannya sudah menggunakan berbagai model pembelajaran, antara lain model menghapal, menyanyi dan bercerita. ${ }^{5}$

Adapun, sifat-sifat yang perlu ditanamkan kepada mereka yang masih Usia Dini adalah kesenangan membaca seperti terma dalam Al-quran yaitu iqra'(QS.al- 'Alaq, 1) serta mendorong rasa keingintahuan mereka yang tinggi seperti dorongan Allah untuk menggunakan akal yang dimiliki setiap manusia tergambar dalam termaapala takkilun dan apala tatafakkarun di samping sifat-sifat utama lainnya. ${ }^{6}$

Pendidikan ini di Nusantara mengalami perkembangan yang cukup pesat.Pendidikan yang semula belajar mengambil tempat-tempat tersebut berkembang pelaksanaannyadi ruang kelas di sebuah bangunan tertentu sebagaimana layaknya sebuah lembaga pendidikan.Lembaga pendidikan itu dinamakan TamanKanak-kanak Al-quran atau Taman Pendidikan Al-quran. Lembaga pendidikan ini saat ini memiliki santri 8.400.000 lebih.

Dalam konteks pendidikan Al-quran ini berkembang pula tradisi lama yaitu Tahfiz Al-quran.Menghapal Al-quran semakin berkembang hingga hari ini yang dikembangkan oleh para Huffaz di Rumah Tahfiz dan berbagai pondok pesantren.

\footnotetext{
${ }^{4}$ Dit. PD. Pontren, Pola pembinaan TKQ (Jakarta: Dit. PD. Pontren, 2013), hal. 3

${ }^{5}$ Dit.PD.Pontren, Pedoman kurikulum TKQ/TPQ, (Jakarta: Dit. PD. Pontren, 2013), hal. 1

${ }^{6}$ Harun Nasution, Islam Rasional, (Bandung: Mizan, 1989), hal. 140
} 
Tradisi menghapal sudah lama ada bahkan sejak masa Rasulullah.Para Shahabat Nabi memiliki keistimewaan dengan kekuatan hapalannya.Pada masa itu tradisi menulis masih langkah, alat perekam belum ada, alap perekamnya di daya hapal yang dimiliki para Shahabat.Kombinasi Shahabat yang mampu menulis yang jumlahnya hanya sedikit dengan para penghapal dari para Shahabat telah meninggalkan warisan mushaf Al-quran yang berisi 6000 lebih ayatnya saat ini ${ }^{7}$.

Sebagai lembaga pendidikan di samping untuk memelihara autentisitas Al-quran juga sebagai khazanah ibadah, yang dijamin para penghapal Al-quran sebagai ahli surga, lembaga ini di masa mendatang semakin berkembang dan akan menampung santri dalam jumlah yang cukup besar, maka harus juga menyesuaikan dirinya dengan tuntutan zaman.

Santri yang berjumlah ratusan ribu misalnya, para huffaz ini perlu pula mengembangkan potensi membaca dan potensi rasa keingintahuan yang tinggi.Kelak mereka akan menjadi dewasa dan akan kembali ke masyarakat seperti masyarakat lainnya.Kembali ke masyarakat setelah selesai belajar, tentu perlu berbagai keahlian di tengah masyarakat bukan hanya keahlian menghafal Al-quran saja yang belum menjadi profesi yang menunjang dalam kehidupannya.Tetapi mereka kelak akan berkiprah di tengah masyarakat menjadi pedagang, petani atau keahlian dalam bentuk lain atau mereka menjadi penggerak perubahan di tengah masyarakat (social community of chang).

Sebelum berkembang pendidikan tahfidz non formal di Nusantara telah berkembang pula lembaga pendidikan tahfiz Al-quran tingkat pendidikan tinggi yang mengambil nama Perguruan Tinggi Ilmu Al-quran (PTIQ) bagi mahasiswa putra dan Institut Ilmu Al-quran (IIQ) bagi mahasiswi. Di peguruan tinggi ini memiliki beberapa jurusan seperti di IAIN yakni jurusan Syariah, Tarbiyah, Ushuluddin dan para mahasiswa/i di samping menghapal Al-quran, juga belajar tentang qiraah sab'ah.Tetapi sesungguhnya bila mengambil semangat dari ayat-ayat Al-quran bukan saja diambil dari sisi historis bagaimana proses terkumpulnya Al-quran yang memunculkan Mushaf Usmani dan juga ada qiraah sab'ah dengan beragam versi bacaannya. Tetapi yang esensial sebetulnya bagaimana kita mengkaji Al-quran yang berkaitan dengan materi kandungannya.Pada Al-quran seakan kita melihat seluruh spektrum kehidupan

\footnotetext{
${ }^{7}$ Fahmi Irfani, Potret Pendidikan Islam Pada Masa Klasik (Dinasti Abbasiyah dan Ummayah), Jurnal Fikrah, Volume 7 No 1. Hal 35
} 
manusia.Al-quran berbicara tentang manusia yang berkaitan dengan ekonomi, pendidikan, hukum, etika, politik; hingga masalah alam semesta yang luas.Kajian Alquran apalagi pada tingkat tinggi memberi tempat untuk mengkaji hal-hal tersebut.Karena itu kajian Al-quran harus lebih menukik pada soal-soal yang teknis tentang persoalan-persoalan manusia.Al-quran tidak cukup dihapal, tetapi perlu dikaji dari sisi yang lebih luas, memerlukan filosofis yang mendalam dan memerlukan prespektif ilmu-ilmu umum.

Pendidikan Islam lainyakni Pendidikan Pesantren.Pendidikan pesantren pendidikan indigenous Nusantara.Satu sumber menyatakan institusi pendidikan ini telah ada pada masa Walisongo yang didirikan oleh Raden Rahmad pada abad 16 di daerah Gresik Jawa Timur. ${ }^{8}$ Di luar Jawa pendidikan agama ada yang disebut dengan surau seperti di Sumatera Barat, dayah di Aceh dan langgar di Sumatera Selatan. Kini namanama itu telah menjadi trade mark disebut dengan pesantren. Dalam pandangan Zamakhsjari Dofier, Pendidikan pesantren memiliki empat ciri: yakni ada masjid, kyai, santri dan ada kitab kuning sebagai materi kajiannya. ${ }^{9}$

Sebenarnya, awal mula mengkaji agama dilakukan di rumah guru mengaji (ustadz), ada pula belajar agama dilakukan di masjid.Lama kelamaansantri semakin banyak di dua tempat itu tidak lagi memadai maka dibuatlah suaru tempat untuk belajar agama. Belajar agama ke kyai yang tersohor telah mengundang mereka yang tinggal letaknya jauh dari seorang kyai, maka untuk itu dibuatlah tempat mereka menginap atau berdiam dalam jangka waktu tertentu.Dengan demikian tampaknya pendidikan agama mengalami dinamika dari rumah atau masjid, ke tempat yang khusus untuk belajar agama yang kemudian disebut dengan pesantren.Pendidikan model ini dapat dikatakan sepanjang waktu kecuali tidur dan ibadah shalat.Anak didik disamping belajar agama melalui kitab kuning yang menggunakan metode sorogan, bandongan dan halaqah. ${ }^{10}$ Sistem pendidikan yang diterapkan penjajah mempengaruhi pula pendidikan di pesantren, terutama dalam materi pelajaran, mereka bukan saja belajar agama tetapi juga belajar ilmu aljabar, sejarah dan lainnya.Inilah tonggak dinamika yang substantif di

\footnotetext{
${ }^{8}$ Hasbi Indra, "Pesantren dan Peradaban”,Jabal Hikmah, STAIN Jayapura, Vol. 2. No. 4 Juli 2009, hal. 211

${ }^{9}$ Zamakhsjari Dofier, Tradisi Pesantren, (Jakarta: LP3ES, 1994), hal. 44

${ }^{10}$ Zamakhsjari Dofier, Tradisi Pesantren, hal. 44
} 
pesantren, ${ }^{11}$ di samping menanamkan kharakter pada santrinya seperti mandiri, tanggung jawab dan lainnya.Kemudian di dalam pesantren juga didirikan sekolah formal seperti SMP atau SMA. Ada pula pesantren yang disebut pesantren modern, penyelenggaraan pendidikannya di ruang kelas.Di lembaga ini praktek bahasa dibiasakan bagi santrinya terutama bahasa Arab dan bahasa Inggeris, selain menanamkan kharakter santri dan juga santrinya diberikan berbagai skill untuk kehidupannya kelak setelah lulus. ${ }^{12}$

Posisi pesantren saat ini menampung sekitar 3.8 juta lebih santri bagian generasi bangsa ke depan. Tuntutan atau dinamika zaman perlu di respon oleh pesantren dengan berbagai perubahan dalam pengelolaan pendidikannya.Perubahan memang diperlukan dan hal itu sesuatu yang abadi sepanjang kehidupan manusia, sepanjang hal itu sesuatu yang baik.Dalam dunia pesantren sebenarnya telah dipegang kaidah al-muhafazhatu 'ala al-qadimi al-shalih wa al-akhdzu bi al-jadidi al-ashlah/ memelihara khazanah lama yang baik dan mengambil yang baru yang baik. ${ }^{13}$

Lalu Pendidikan Diniyah.Pendidikan Diniyah umumnya didirikan oleh masyarakat.Sebenarnya Pendidikan Diniyah telah berdiri sejak era penjajahan yang bentuk penyelenggaraannya beranekaragam.Pada waktu itu Pendidikan Diniyah mendapat bantuan dari para Sultan selaku penguasa setempat.Setelah Indonesia merdeka, Pendidikan Diniyah mendapat dukungan dalam Maklumat BPKNIP Tanggal 22 Desember 1945, bahwa dalam memajukan pendidikan dan pengajaran sekurangkurangnya diusahakan agar pengajaran yang berlangsung di langgar, surau, masjid dan madrasah berjalan terus. Kemudian dalam upaya peningkatan kualitas Pendidikan Diniyah diupayakan diantaranya dengan Peraruran Menteri Agama No. 3 Tahun 1983 Tentang Kutikulum Madrasah Diniyah yang bertujuan untuk meningkatkan mutu pendidikan, sehingga cita-cita pendidikan pada Pendidikan Diniyah dapat dicapai secara selektif.

Awal didirikan Pendidikan Diniyah pada masa penjajahan salah satunya dimaksudkan untuk memberikan pelajaran agama bagi anak-anak Muslim yang buta dengan agamanya.Kemudian pada masa kemerdekaan dimaksudkan pula agar anakanak Muslim memiliki pemahaman agama dan pengamalannya yang cukup bagi siswa

\footnotetext{
${ }^{11}$ Azyumardi Azra, Esai-esai Intelektual Muslim dan Pendidikan Islam, (Jakarta: Logos, 1998), hal. 87

${ }^{12}$ Hasbi indra, "Manajemen Pendidikan Islam", Tawazun, Pascasarjana Univ. Ibn Khaldun, Vol. 4 No. 4-Juli 2010, hal. 3

${ }^{13}$ Hasbi Indra, "Pesantren dan Peradaban", hal. 217
} 
yang belajar di sekolah umum.Selain itu, ada pula Pendidikan Diniyah yang diselenggarakan di pesantren, juga dimaksudkan untuk mendalami ajaran agama Islam serta mengamalkannya secara konsisten. ${ }^{14}$

Dalam kaitan kurikulum Pendidikan Diniyah sesuai dengan keputusan Menteri Agama No. 3 Tahun 1983 membaginya menjadi 3 tingkatan, yaitu Diniyah Awaliyah, Diniyah Wustha dan Diniyah Ulya. Kemudian pada Tahun 1991 kurikulumnya dikembangkan menjadi 3 tipe, yaitu: tipe A berfungsi membantu dan menyempurnakan pencapaian tema sentral pendidikan agama pada sekolah umum terutama dalam hal praktik dan latihan ibadah serta membaca Al-Qur'an; (2) tipe B berfungsi meningkatkan pengetahuan agama Islam sehingga setara dengan Madrasah. Pendidikan Diniyah ini berorientasi kurikulumnya ke Madrasah Ibtidaiyah, Madrasah Tsanawiyah dan Madrasah Aliyah; (3) tipe $\mathrm{C}$ berfungsi untuk pendalaman agama dengan sistem pondok pesantren.Materi pembelajarannya berkisar pelajaran Al-Qur'an, Akidah-Akhlak, Ibadah, Sejarah Kebudayaan Islam dan Bahasa Arab. ${ }^{15}$

Pendidikan Diniyah yang mendidik 4.143.604ini perlu mendapatkan peningkatan, karena sebagai lembaga pendidikan yang dilindungi Undang-undang, dan ikut mencerdaskan anak didik, para gurunya yang menggantungkan hidupnya di lembaga ini diperlukan perhatian yang sama dengan model pendidikan lainnya.Kurikulum yang integratif yang berbasis kompetensi sangat penting untuk diterapkan di lembaga pendidikan ini untuk menyiapkan anak didik memhami meteri pendidikan agama yang dalam.Untuk menopang kualitasanak didikkualitas guru masih perlu ditingkatkan melalui pelatihan, dan memerlukan sarana prasarana pendidikan lainnya.

Pendidikan jenis lain adalah madrasah.Madrasah adalah lembaga pendidikan yang memberikan pelajaran agama Islam dan pelajaran non agama pada tingkat rendah dan menengah.Madrasah berkembang di berbagai daerah di seluruh Indonesia baik yang diselenggarakan pemerintah maupun oleh swasta.Pendidikan ini sudah lama menyerap sistem pendidikan modern, baik pengelolaannya maupun proses pembelajaran serta materi pelajaran yang bukan saja belajar agama tetapi juga belajar ilmu-ilmu umum. Munculnya model pendidikan Madrasah ini karena adanya persentuhan atau kontak langsung dengan model pendidikan Barat melalui ulama yang pernah belajar di Timur

\footnotetext{
hal. 1

${ }^{14}$ Dit. PD. Pontren, Pola Pengembangan Madrasah Diniyah, (Jakarta: Dit. PD. Pontren, 2007),

${ }^{15}$ Dit. PD. Pontren, Pola Pengembangan, hal. 4
} 
Tangah. Model pembelajaran Madrasah diadakan seperti model pembelajaran sekolah umum, belajar di ruang kelas dan bertingkat serta dilakukan evaluasi tengah tahunan dan tahunan.

Sejak tahun 1969 di pendidikan ini telah diberikan mata pelajaran agama juga mata pelajaran non agama.Misalnya dalam kurikulum Madrasah Ibtidaiyah matapelajaran Agama terdiri dari belajar membaca Al-Qur'an, Tauhid, Fiqh dan Ushul Fiqh, Tafsir dan Hadits serta Akhlak. Adapun mata pelajaran umum seperti Bahasa Indonesia, Berhitung, Ilmu Bumi, Sejarah, Ilmu Alam, Menggambar dan pekerjaan tangan. Begitu pula gambaran kurikulum Madrasah Tsanawiyah, pelajaran agamanya Tafsir, Hadits/Musthalah, Tauhid, Fiqh/Hikmah Tasyri' dan Ushul Fiqh, Tarikh Islam; adapun mata pelajaran umum yakni: Ilmu Bumi, Ilmu Alam, Ilmu Tumbuh-Tumbuhan, Ilmu Hewan, Ilmu Tubuh Manusia, Ilmu Berhitung, Bahasa Inggris, dan gerak badan. Pendidikan Madrasah pada masa pasca penjajahan dimaksudkan untuk memberikan pengetahuan agama dan wawasan ilmu umum untuk memenuhi kebutuhan umat Islam sendiri seperti memimpin ritual umat Islam.

Di masa kemerdekaan pendidikan ini semakin banyak didirikan oleh masyarakat yang kemudian banyak dinegerikan oleh pemerintah, selain pemerintah sendiri ada mendirikan Madrasah. Lulusannya tidak hanya dapat bekerja menjadi pegawai negeri seperti di Departemen Agama setelah selesai dari Madrasah Aliyah, mereka juga dapat meneruskan ke IAIN atau STAIN. Pendidikan Madrasah pada dekade 70-andi tambah materi pelajarannya denganpendidikan orkes,pendidikan seni, dan pendidikan keterampilan yaitu Administrasi Urusan Agama dan Peradilan Agama serta Bimbingan dan Penyuluhan Agama.

Lalu pada era berikutnya pendidikan ini mengalami dinamika sesuai dengan tuntutan zaman dengan dibuat Kesepakatan 3 Menteri yakni Menteri Agama, Menteri Dalam Negeri dan Menteri Pendidikan dan Kebudayaan. SKB 3 Menteri itu memberi peluang lulusan Madrasah bukan saja dapat bekerja di Departemen Agama tetapi juga di departemen lain, dan juga mereka dapat melanjutkan pendidikannya ke universitas umum, seperti melanjutkan ke Fakultas Kedokteran, Teknik, Hukum dan sebagainya. Untuk itu dibuatlah kurikulum tingkat Ibtidaiyah, Tsanawiyah dan Aliyah kelas 1 dan 2, dan kelas 3 dibagi ke dalam 4 Program Studi yaitu Agama Islam, Bahasa, Ilmu Sosial dan Ilmu alam. 
Berdiri pula Madrasah Aliyah Program Khusus (MAPK), yaitu mata pelajarannya hampir semua mata pelajaran agama dan penguasaan bahasa Arab bagi siswanya menjadi mutlak. Juga Madrasah Aliyah Keterampilan (MAK), dimana siswa Madrasah di samping belajar agama juga belajar ilmu keterampilan seperti perbengkelan, jahitmenjahit, elektronik dan lainnya agar kelak mereka selesai pendidikannya dapat langsung turun di dunia kerja. ${ }^{16} \mathrm{Di}$ pendidikan madrasah dididik siswa/I dalam kisaran 8.230.788 juta (teramasuk siswa/siswi Raudhatul atfal).

Di pendidikan ini, sebagairnana dikatakan Aminuddin Rasyad, Guru Besar Ilmu Pendidikan UIN Jakarta, muatan pembelajarannya sangat padat, belasan disiplin ilmu yang terpisah antara ilmu agama dengan ilmu umum harus dikuasai. Sebagaimana organ tubuh yang lain dari manusia mengalami kelelahan, maka otak manusia pun juga ada batasnya dan mengalami kelelahan. Segudang teori diberikan tetapi hanya sebagian kecilnya saja yang diperoleh atau dipahami, maka segi afektifnya saja yang terjamah, tetapi segi psikomotorik hanya sedikit yang tersentuh.Maka, ketika ada penerapan antara teori dengan praktik sering tidak sejalan dan dalam bentuk riilnya dapat dilihat masih belum siap mereka terjun di dunia kerja atau dalam bentuk aplikasi moralitas di masyarakat terasa semakin memprihatinkan. ${ }^{17}$

Kemudian pendidikan tinggi Islam seperti IAIN/STAIN/UIN/STAIS/UIS, adalah pendidikan tinggi yang mendidik dalam kisaran 601.312 mahasiswa/I dapat mengembangkan berbagai keilmuan. Pendidikan ini gerbang mencetak cita-cita AlQur'an misalnya ayat yang berbunyi innama yakhsallah min ibadih al-'ulama', artinya " Sesungguhnya orang yang takut kepada Allah adalah ulama " (QS. Fatir. 28), kemudian hadits menyatakan al-'ulama waratsat al-ambiya' artinya ulama itu adalah pewaris para Nabi, begitu tinggi derajat ulama itu karena ia pewaris para Nabi. Ulama menurut terminologi, ialah seorang yang ahli agama Islam baik menguasai ilmu fiqh, ilmu tauhid atau ilmu agama lainnya, dan mempunyai integritas kepribadian yang tinggi, berakhlak mulia serta berpengaruh di masyarakat. Namun, pengertian ulama dalam perkembangannya yaitu berarti orang yang mendalami ilmu pengetahuan, baik ilmu pengetahuan yang bersumber dari Allah SWT., yang kemudian disebut 'ulum al-din, maupun ilmu pengetahuan yang bersumber dari hasil penggunaan potensi akal dan indra

\footnotetext{
${ }^{16}$ Marwan Saridjo, Pendidikan Islam Dari Masa ke Masa, (Jakarta: Penamadani, 2010), hal. 120

${ }^{17}$ Aminuddin Rasyad, Majalah Ikhlas, Depag, No. 22 tahun 16, 2002, hal. 11
} 
manusia dalam memahami ayat kauniyah yang kemudian disebut dengan 'ulum alinsaniyah atau al-'ulum atau sains. ${ }^{18}$

Pendidikan Tinggi Islam di Indonesia mulanya berdiri pada Tahun 1940 yang bernama Sekolah Tinggi Islam (STI) oleh Persatuan Guru Agama Islam di Padang.Kemudian pada Tahun 1945, sebulan sebelum Proklamasi Kemerdekaan Republik Indonesia atas prakarsa tokoh-tokoh Islam yang diketuai oleh Moh. Hatta dan sekretarisnya Mohammad Natsir didirikanlah Sekolah Tinggi Islam di Jakarta dengan pimpinan Prof. Kahar Muzakkir, kemudian (STI) dipindahkan ke Yogyakarta pada Tahun 1946 mengikuti berpindahnya pusat pemerintah RI. Di Jakarta didirikan pula Akademi Dinas Ilmu Agama berdasarkan penetapan Menteri Agama No, 1 Tahun 1957.Kemudian didirikan pula Perguruan Tinggi Agama Islam (PTAIN) yang diambil dari fakultas agama Universitas Islam Indonesia berdasarkan Peraturan Pemerintah No. 34 Tahun 1950.Demikian luas cakupan ilmu agama Islam yang meliputi berbagai aspek dan semakin mejemuknya pola pengembangan kehidupan sosial, maka pengembangan ilmu agama Islam semakin kehilangan geraknya bila hanya difokalisir dalam satu fakultas. Maka, diterbitkanlah Peraturan Presiden No. 11 Tahun 1960 yang menggabungkan PTAIN di Yogyakarta dan ADIA di Jakarta pada Tanggal 9 Mei 1960, menjadi Institut Agama Islam Negeri dengan nama al-Jami'ah al-Islamiyah alHukumiyah yang berkedudukan di Yogyakarta dan Jakarta. ${ }^{19}$

IAIN merupakan pusat pengembangan dan pendalaman agama Islam. IAIN diharapkan memproduk sarjana Muslim yang mempunyai keahlian dalam ilmu agama Islam, berakhlak mulia, cakap dan bertangungjawab atas kesejahteraan umat serta masa depan bangsa Indonesia.Institusi ini merupakan lemabaga bagi anak didik atau santri lulusan Madrasah, Madrasah Diniyah dan Pesantren untuk melanjutkan pendidikannya.

Selain tempat memproduk ahli agama (ulama) juga harapan pemerintah untuk mengisi birokrasi pemerintahan di Departemen Agama. Departemen Agama yang didirikan untuk memberikan pelayanan kepada umat beragama di Indonesia. Departemen Agama ini mengurus semua agama yang diakui pemerintah seperti Islam, Kristen, Katolik, Hindu dan Budha serta Konghucu.Di Departemen Agama terbentuk berbagai urusan yang berkaitan dengan urusan Haji, urusan Penerangan, dan urusan

\footnotetext{
1996), hal. 32

${ }^{18}$ Sahirul Alim, Menguak Keterpaduan Sains, Teknologi dan Islam, (Yogyakarta:Dinamika,

${ }^{19}$ Marwan Saridjo, Pendidikan islam, hal. 188
} 
Pendidikan dan lainnya.Maka, dengan berkembangnya birokrasi Departemen Agama, tentu saja yang diharapkan untuk mengisinya adalah mereka yang berasal dari perguruan tinggi agama Islam seperti IAIN.

Tuntutan untuk mencetak ahli agama dan juga untuk mengisi birokrasi pemerintahan, semakin besar di berbagai propinsi di Indonesia, maka Institut Agama Islam Negeri (LAIN) tersebar di seluruh Indonesia. Di beberapa provinsi dan kabupaten berdiri LAIN Cabang, seperti di provinsi Pontianak ke LAIN Syarif Hidayatullah Jakarta, LAIN Bengkulu dan Curup yang berada di Kabupaten berinduk ke IAIN Palembang.

Jumlah IAIN sudah demikian banyak dan karenanya di beberapa IAIN di Cabang kesulitan untuk mencari mahasiswanya.Maka ada di institusi ini yang di diskualifikasi. Kemudian ada pula pembaharuan dalam manajemen pengelolaannya, kalau sebelumnya bercabang ke IAIN induk, kini mereka sudah mandiri dan di LAIN Cabang ini berubah nomenklaturnya menjadi Sekolah Tinggi Agama Islam Negeri (STAIN). Di IAIN memiliki beberapa fakultas seperti Fakultas Syariah, Tarbiyah, Adab, Ushuluddin dan Dakwah, begitu pula di STAIN memiliki program studi paling tidak dua program studi yaitu Syariah dan Tarbiyah atau program lainnya.

Kurikulum yang diberikan pada mahasiswa mengalami perkembangan, kalau sebelumnya didominasi mata kuliah agama, mengalami perkembangan maka diberikan mata kuliah ilmu umum dalam jumlah yang cukup banyak. Misalnya di Fakultas Syariah, bukan saja mata kuliah agama seperti Fiqh, Hadits, Tafsir, Tauhid, tetapi juga mata kuliah umum seperti Manajemen, Sosiologi, Pengantar Ilmu Hukum, Hukum Tata Negara, Hukum Perdata, Hukum Pidana dan lainnya. Juga hal yang sama diberikan mata kuliah agama dan umum di fakultas-fakultas lainnya. Penambahan mata kuliah umum dimaksudkan untuk menambah ilmu dan wawasan mahasiswa sehingga sangat berguna ketika ia selesai di perguruan tinggi agama Islam ini.

Kemudian di beberapa IAIN merubah dirinya menjadi UIN seperti Syarif Hidayatullah Jakarta, UIN Sunan Kalijaga Yogyakarta dan UIN Sunan Ampel Malang, UIN Syarif Qosim (SUSQO) Pekan Baru dan di beberapa UIN lainnya. ${ }^{20}$ Perubahan ini salah satunya atas dasar pertimbangan sebagai upaya untuk melakukan Islamisasi ilmu pengetahuan atau paling tidak melakukan integrasi keilmuwan yang pernah menjadi

\footnotetext{
${ }^{20}$ Azyumardi Azra, “Upaya IAIN Menjawab Tantangan Zaman”, Perta, Vol. V/No. 01/2001, hal. 75
} 
wacana hangat di Indonesia. Integrasi keilmuwan agama biasanya bagian dari reasoning utama munculnya UIN. Cita-cita tersebut memang bersifat idealis tentu saja butuh waktu untuk membuktikan apakah cita-cita integrasi keilmuwan akan menemui kenyataan.

Melihat fenomena semakin banyaknya IAIN berkeinginan menjadi UIN, karena dari segi animo mahasiswa cukup besar, maka UIN di masa mendatang semakin bertambah.Hanya saja pendirian IAIN ke UIN memunculkan pertanyaan, apakah produknya terutama program-program umum seperti kedokteran, teknik informatika dan lainnya hanya menambah daftar lulusan yang unggul dalam bidang teori?Atau hanya memproduk lulusan untuk memenuhi tenaga pengajar di pendidikan tinggi tetapi lemah dalam bidang riset, yang hasilnya hanya pandai berteori namun belum bisa mengembangkan ilmu? Jika demikian, nasib UIN akan sama dengan pendidikan tinggi di berbagai Negara Islam yang belum memberikan kontribusi maksimal dalam pengembangan keilmuwan baik dalam sains maupun teknologi. Atau produknya hanya dapat melegitimasi dan fasih berbicara istilah-istilah keilmuwan dan sejarah perkembangan sains dan teknologi, dan bahwa kemajuan serta penemuan sains dan teknologi ada dalil atau nashnya di dalam Al-Qur'an dan Hadits?Hanya sekedar itu?

Produk IAIN/STAIN atau UIN/UISdalam studi agama harus pula bersaing dalam mengisi berbagai kebutuhan masyarakat Misalnya bagaimana kiprah lulusan Fakultas/program studi Syariah dalam dunia advokasi bukan saja dalam bidang perkawinan, waris tetapi terhadap advokasi HAM dan lainnya. Begitu pula dengan produk Fakultas Dakwah, harus dapat mereka yang ahli membuat scenario film, menjadi produser. Begitu pula dengan produk Fakultas Adab menelorkan sastrawan, sejarawan, alumninya fasih berbahsa arab, fakultas uhuluddin menjadi ilmuan yang tangguh, dan fakultas Tarbiyah menelorkan kurikulum dan model pembelajaran yang mengantarkan anak didik menjadi kreatif guna mengantarkan manusia Indonesia berkompetsi di era global.Di samping itu pendidikan Islam harus juga menelorkan peneliti atau periset yang handal.

\section{Tujuan Pendidikan Islam}

Pendidikan Islam saat ini dan ke depan tidak cukup memadai lagi hanya memiliki semangat untuk memelihara dan membela nilai-nilai ilahiyah yang bersifat normatif yang berkaitan dengan kehidupan manusia, tetapi juga mengembalikan semangat yang 
telah lama hilangyaitu mengembangkan nilai-nilai tersebut dalam bentuk yang aplikatif, terutama yang berkaitan dengan intrumen-instrumen kehidupan yang membentuk peradaban manusia saat ini. Kehidupan manusia kini yang sudah demikian maju dan canggih sebagai hasil kemajuan ilmu dan teknologi, Muslim masih ada waktu untuk ikut berperan sehingga tidak cukup hanya sebagai konsumen ilmu dan teknologi tetapi berupaya untuk menjadi produsen keduanya.

Ke depan tantangan pendidikan Islam menyiapkan anak didik siap dalam mengadapi kompetisi kehidupan. Salah satunya melalui kurikulum mengefektifkan pembelajaran yang lengkap, konprehensif, bersungguh-sungguhatau serius belajar ilmu agama juga ilmu umum yang pembelajarannya dengan tenaga pendidik yang handal.Pendidiikan Islam harus pula membentuk optimisme anak didiknya, bukan melemahkannya, Pendidikan Islam harus menseimbangkan kehidupan ini, karena manusia masih berada dalam kehidupannya di dunia yang sebagian besar waktunya untuk berikhtiar; dan ikhtiarnya bernilai ibadah baginya. ${ }^{21}$ Pendidikan Islam hendaklah diarahkan untuk memaksimalkan dan mengoptimal fungsi akal, rasa dan psikomotorik.Institusi ini dapat memberikan perannya yang maksimal baik dalam keilmuan maupun pembentukan kharakter anak didik untuk pembangunan bangsa.

Hasil pendidikan yang akandiperoleh adalah kemajuan bangsa yang luar biasa dalam kehidupan masyarakatnya, produks pendidikannya melahirkan manusia-manusia kreatif yang melahirkan berbagai hasil teknologi, dan lebih jauh lagi membentuk manusia yang bermental enterpreneurshif sehingga kelak ikut mengantarkan negara ini menjadi maju, dan berkharakterbaik.Sikap hidup yang sebenarnya original Islam seperti hidup disiplin, jujur dan bertanggungjawab, tingkat korupsi yang rendah dan lainnya.

Pendidikan Islam yang umumnya membentuk anak shalih yang umumnya dipahami hanya taat beribadah, menghindari larangan-larangan Allah, hormat pada orang tua.Tetapi lebih jauh lagi seharusnya dipahami pula adalahanak didik yang cerdas lagi kreatif/fathanah, amanah, berprilaku jujur, disiplin, tanggungjawab, mandiri, memiliki jiwa enterpreneurshif yang banyak ditemukan di masyarakat Negara maju. Apabila PendidikanIslam tidak menyesuaikan diri maka sebagian besar dari produks pendidikan ini tidak dapat memberi peran maksimal terhadap bangsa, bahkan akan menjadi penonton dalam pembangunan bangsa ini ke depan.

\footnotetext{
${ }^{21}$ Iktiyar atau kerja untuk dirinya maupun untuk sosial dengan niat baik termasuk 'amal shalih berdampak pahala merupakan pengamalan ayat Al-quran, suratal-Ra'dlu, 39 dan al-Zilzalah, 7.
} 
Melalui materi pembelajaran nash-nash Al-quran, misalnya ayat-ayat yang berkaitan dengan tantangan Allah agar manusia berfikir, berakal, dan meneliti alam semesta perlu diperhatikan. ${ }^{22}$ Para ulama telah memberi contoh pada masa lalu dalam konteks kreatifitasnyatelah menggali dari sumber Al-quran, mereka membuahkan ilmu tafsir, hadits, fiqh dan ilmu bahasa arab. Melalui semangat Al-quran pula ulama-ulama Muslim telah memelihara dan mengembangkan berbagai ilmu pengetahuan, seperti ilmu kedokteran, kimia, fisika, matematika dan lainnya. ${ }^{23}$ Etos keilmuan yang membuahkan hasil kreatifitas mereka seharusnya diwarisi oleh produk pendidikan Islam masa kini dan mendatang.

Juga untuk menumbuhkan etos ekonomi di semua Pendidikan Islam perlu ditampilkan nash-nash ekonomi yang menggerakkan seperti ayat 10 Surat al-Jumu'ah yang intinya setelah selesai shalat jum'at bersegeralah untuk mencari rezeqi, serta segera memberi contoh nyata agar kelak anak didiknya memiliki jiwa entepreneurshif, di berbagai lembaga Pendidikan Islam jadikan lembaga mandiri tidak bergantung ke pihak lain. Dirikanlah di lembaga pendidikannya lembaga koperasi atau lembaga usaha pengembangan ekonomi, dan melibatkan anak didiknya sehinga akan terkesan secara mendalam di benaknya danakan tumbuh jiwa enterpreneurshif tersebut.

Untuk menunbuhkan mental entepreneurshif anak didik adalah perlu mendapatkan contoh dari pemimpinnya.Mereka melihat ada contoh yang dapat melemahkan jiwanya dari contoh para pemimpin pendidikan. Mereka melihat di lembaga pendidikan Islam dimana ia belajar tidak ada usaha ekonomi, tetapi pemimpinnya memiliki rumah yang besar, mobil yang bagus, mengajar sekali sehari, hidup sang pemimpin santai saja, ini akan menjadi contoh negatif bagi santri sebagai protypnya dalam kehidupan.

Untuk itu Pendidikan Islam harus juga mengevaluasi materi-materi yang melemahkan etoshidup, etos ilmu dan etos kerja.Menghindari memberikan nilai-nilai yang membuat anak didik pasimisme dalam menghadapi hidup.Muslim harus mewarnai hidup ini sembari merupakan bentuk pengabdiannya kepada Tuhan dan berpahalajuga baginya, etos- etos tersebut harus terus ditumbuhkan. Kepasrahan, ihklas dan lainnya pasti akan dimiliki ketika ia sudah melakukan daya upaya dalam hidupnya, nilai-nilai fasrah, mencari yang mudah, malas, tidak ada motivasi, hal-hal yangsudah melekat pada setiap manusia, tetapi etos-etos ikhtiyar atau positif itu harus terus dipompa karena

\footnotetext{
${ }^{22}$ Harun Nasution, Islam Rasional, hal. 140

${ }^{23}$ Harun Nasution, Islam Rasional,hal. 298
} 
memerlukan suntikan terus menerus. Malalui hal itu akan tumbuh cinta ilmu, cinta kerja dan juga memiliki jiwa enterpreneurshif.

Selain itu ada pula tujuan pendidikan Islam yang secara komunitas ingin membentuk umat terbaik seperti firman Allah suratali-Imran, 110 bunyinya:

Kuntum khaira ummatin ukhrijat linnas ta'muruna bilma'ruf watanha 'anil munkar.

Arti bebasnya: "bahwa umat Islam adalah umat terbaik atau umat yang sukses dalam kehidupan, umat yang menguasai ilmu dan teknologi, umat yang maju ekonominya, umat yang berakhlak mulia, patut untuk memanggil umat yang lain untuk berada dalam kebenaran ('amal ma'ruf nahi munkar").

Komunitas atau jama'ah sangat ditekankan dalam ibadah Islam.Ibadah seseorang yang dilakukannya bersama komunitasnya seperti melakukan shalat fardhu berjama'ah, tarawih berjama'ah, shalat 'id berjama'ah hal yang sangat dianjurkan agama, ini adalah model hidup Muslim-yakni kebersamaan. Sementara hidup menyendiri, atau dalam bentuk seperti hidup yang hanya sibuk dengan dirinya sendiri dalam bentuk berzikir, khusuk-maksyuk sendiri, diharapkan ia dekat ke Al-khaliq, ia tidak hirau dengan apa yang terjadi di lingkungan, apalagi yang terjadi di negara, adalah jalan hidup yang hanya mementingkan dirinya sendiri? (individualisme), sikap yang bertentangan dengan spirit Shalat berjama'ah yang dianjurkan oleh Al-quran maupun Al-hadits. Apakah pola hidup Muslim sama dengan pola hidup individualisme sebagaimana yang sering dituduhkan ke banyak Negara barat?

\section{Tantangan Pendidikan Islam}

Pendidikan Islam saat ini hidup di era globalisasi.Era yang ditandai oleh kemajuan yang dihasilkan oleh rekayasa manusia, saat ini telah memunculkan ratusan satelit komunikasi di orbit geo-stationer yang bergerak anggun mengikuti rotasi bumi.Sementara itu ribuan kilometer kabel serta optik merambah di dasar samudra.Perkawinan antara teknologi transmisi mutakhir ini dengan komputer telah melahirkan sebuah era baru, yaitu era informasi.Suatu era dimana manusia bisa saling berhubungah dari ujung bumi yang satu ke ujung lainnya dalam kecepatan nanosecond.Era dimana pengiriman data lintas batas wilayah, konferensi jarak jauh, pengiriman melalui faximile dan cetak jarak jauh bukan lagi suatu khayalan.Era dimana 
program televisi dari satu Negara dapat ditonton secara serentak oleh ratusan juta pemirsa di puluhan Negara.Era dimana menurut Madjid one the world one globe. ${ }^{24}$

Seiring dengan kian lajunya kontak melalui beragam media, pertemuan langsung antar manusia juga terjadi dengan sangat intens akibat kemajuan-kemajuan yang mencengangkan dalam bidang transportasi laut, udara dan darat. Jutaan turi $i_{\mathrm{s}}$ internasional lalu lalang dari kontinen yang satu ke kontinen yang lain. Pertemuan dalam bidang IPTEK, terbilang lebih dari 10 ribu pertemuan internasional dilangsungkan setiap Tahun.Sehingga rasanya tidak terlampau berlebihan jika kita menominasikan kata globalisasi sebagai world of year.

Selain kemajuan yang mencengangkan dalam bidang informasi dan transformasi, dicatat pula kemajuan mendasar dalam berbagai bidang IPTEK, antara lain dalam bidang kedokteran, angkasa luar, bioteknologi, energi dan material. IPTEK tiba-tiba menjadi salah satu primadona penting dalam kehidupan umat manusia.Diperkirakan lebih dari 97 persen dari seluruh saintis, pernah lahir dalam sejarah hidup umat manusia saat ini.Tidak mengherankan jika penemuan teknologi baru bermunculan setiap hari.Tidak mengagetkan jika aneka teori yang muncul sudah mampu menerangkan beragam hukum alam, mulai dari hukum yang mengatur gerak orbit dan galaksi kemaharayaan alam semesta sampai yang menerangkan sifat-sifat sub atom.

Betapa dominannya IPTEK dalam mewamai kebudayaan suatu bangsa, termasuk bangsa Indonesia di era globalisasi ini.Tentang globalisasi, salah satu pandangan yang dapat disimak adalah pandangan Akhbar Ahmad dan Hasting.la memberi arti bahwa globalisasi pada dasarnya mengacu pada perkembangan yang cepat di dalam teknologi komunikasi, transformasi, informasi yang dapat membawa bagianbagian dunia yang jauh bisa di jangkau dengan mudah. ${ }^{25}$ Globalisasi merupakan kelanjutan saja dari modernisasi yang pada dasarnya berisi sekularisasi yang isinya merupakan kelanjutan dari misi modern dan posmodernisme yang semakin sekuler, semakin maju dan semakin menjauh dari agama. ${ }^{26}$ Dari sisi lain, globalisasi adalah

${ }^{24}$ Syamsul Arifin, "Strategi Pendidikan Dalam Rangka Menghadapi Globalisasi”, Tarbiya, UIN Syarif Hidayatullah Jakarta, Vo. 2 Des 2014, hal. 171

${ }^{25}$ Akbar S. Ahmad dan Hastings Donnan, Islam Globalization and

Postmodernity,(London:Routledge, 1994), hal.1

${ }^{26}$ Abdurrahman Mas'ud, "Pendidikan Islam dalam Era Reformasi dan Globalisasi", Religia, STAIN Pekalongan, Edisi II/ 2006, hal. 1 
proses pengintegrasian ekonomi nasional kepada sistem ekonomi dunia berdasarkan keyakinan pada perdagangan bebas, apa yang disebut dengan AFTA, GATT, dan lalu MEA. ${ }^{27}$ Yang sejak lama sudah meramalkan, bahwa kapitalisme akan berkembang menuju pada dominasi ekonomi, politik dan budaya berskala global setelah perjalanan panjang melalui era kolonialisme. ${ }^{28}$ Ekonomi kini telah dikuasai oleh semacam libidonomic (nemein-mendistribusikan-libido -energi nafsu), yaitu pendistribusian rangsangan, rayuan, godaan, kesenangan, kegairahan atau hawa nafsu dalam satu arena pertukaran ekonomi.Tidak hanya ada transaksi saham tetapi juga transaksi seksual, tidak hanya ada deregulasi perdagangan tetapi juga deregulasi tubuh, tidak hanya produksi televisi tetapi juga ada produksi ekstasi.

Demikian pula tentang isu demokratisasi pemerintahan, dan HAM. Melalui penetrasi budaya Barat ke bagian dunia lain melalui berbagai alat teknologi canggih membentuk uniform politik dan budaya ala Barat. Berbagai kemajuan dalam bidang ilmu dan teknologi dengan segera dapat pula dijadikan diskursus seluruh kalangan ilmuwan dunia yang dapat mensejahterakan, menentramkan dan memudahkan umat manusia ataukah sebaliknya justru dapat menyengsarakan dan bahkan menghancurkan umat manusia di planet ini.

Juga perkembangan sosialnya.'Alan Touraine misalnya melihat bahwa proses akhir sosial dewasa ini adalah sebagai akibat modernisasi yang telah mencapai titik ekstremnya, yang disebutnya sebagai hipermodernisasi kontemporer. Menurut dia, kehidupan sosial telah kehilangan kesatuannya.Kini manusia tidak lebih sebuah arus perubahan yang terus menerus yang di dalamnya aktor-aktor individu maupun kolektif tidak lagi bertindak sesuai dengan nilai-nilai dan norma-norma sosial. Akan tetapi mengikuti strateginya masing-masing yang berperan di dalam proses perubahan (kapitalisme global) serta tidak tepat lagi sepenuhnya di kontrol oleh kekuasaan Negara. $^{29}$

Proses akhir sosial ini di percepat dengan pencapaian keadaan maksimalnya di tangan media tersebut dengan menciptakan berbagai simulasi relasi sosial. Setiap media informasi bergerak melalui dua arah; keluar ia memproduksi semakin banyak relasi

\footnotetext{
${ }^{27}$ Aryo Baskoro,. "Tantangan dan Peluang.....Center for Risk Management studies Indonesia, diunduh tanggal 3 Oktober 2015

${ }^{28}$ Arif Furchan, Transformasi Pendidikan Islam di Indonesia, (Yogyakarta: Gama Media, 2006), hal. 39.

${ }^{29}$ Yasraf Amir Piliang, Dunia Yang Dilipat,(Bandung: Mizan, 1998), hal. 72
} 
sosial, ke dalam ia justtu menetralisasi relasi sosial dan sosial itu sendiri. Yang ada sekarang bukanlah komunitas yang di ikat oleh satu idiologi politik tertentu, melainkan individu yang satu sama lainnya berlomba dalam sebuah arena duet, kontes tantangan, rayuan dan godaan masyarakat konsumen.

Pornografi lewat jaringan komputer (cyberporn) adalah sebuah tantangan, artinya orang yang merespon tubuh-tubuh virtual tersebut adalah orang yang menjawab tantangan kecabulan, penyempurnaan penampilan tubuh secara virtual lewat teknologi tubuh tertentu adalah sebuah kontes, artinya orang yang terpesona akan kesempurnaan tubuh tersebut adalah orang yang menerima kontes tersebut. Iklan-iklan virtual di televisi adalah sebuah duel. Artinya orang yang merespon makna virtual satu iklan ketimbang makna lain adalah orang yang berpartisipasi di dalam duel tersebut. Di sini realitas sosial tenggelam di dalam hutan rimba virtual sosial.

Era globalisasi juga telah membuka ruang terjadinya gesekan antara nilai-nilai budaya dan agama di seluruh dunia yang memanfaatkan jasa komunikasi transformasi dan informasi sebagai hasil dari modernisasi teknologi.Dengan antena Parabola dan berlangganan Indovision, maka kita bisa menghadirkan dunia luar ke kamar kita melalui pesawat televisi. Kita akan menerima suguhan berita, adegan peristiwa dan semacamnya yang tidak mungkin kita saksikan secara langsung. Dari sekian banyak berita itu dan sekian banyak Negara dan budaya yang bermacam-macam, kita akan dijejali atau dipaksa untuk menyaksikan hal-hal tersebut. Sudah barang tentu dalam program dan acara, baik secara langsung atau dalam pribadi kita akan terjadi gesekan bahkan benturan nilai-nilai budaya dan semacamnya. Contohnya bisa kita perkecil di pragram TV kita, bagaimana dan apa yang terjadi jika kita menyaksikan semua acara di TV, kalau perlu melalui seluruh saluran dari sejak dibuka pagi buta sampai larut malam. ${ }^{30}$

Itulah kira-kira contoh kecil globalisasi yang mempengaruhi nilai agama dan budaya.Tambahan lagi kalau kita pergi ke Mall atau pusat perbelanjaan. Mode pakaian sampai makanan kita juga akan melihat pesan yang dibawa globalisasi. Kita akan sulit sekali untuk menyaksikan orang Jawa memakai blankon dan ibu-ibu yang memakai kebaya, kecuali mereka sedang menerima tamu dalam acara perkawinan. Dari sekian contoh yang paling menonjol adalah nilai dan peran materialisme. Hampir semuanya akan diukur dengan seberapa tebal kantong kita, ketika kita berada di situasi itu.

\footnotetext{
${ }^{30}$ Yasraf Amir Piliang, Dunia...hal. 73
} 
Globalisasi dapat dianggap menjadi ancaman, melalui berbagai media, kita dapat menyaksikan hiburan porno dari kamar tidur kita.Kita dapat terpengaruh oleh segala macam bentuk iklan yang sangat konsumtif.Anak-anak kita dapat terpengaruh segala macam film kartun yang bermuatan buruk dan film yang tidak seharusnya mereka tonton. Anak-anak muda kita dapat terpengaruh dengan mudah oleh gaya hidup yang ditayangkan di sinetron. Dimana sinetron kita 90 persen menebar nilai-nilai yang negatif, tidak memiliki unsur pesan yang edukatif, dengan ukuran keberagamaan dari setiap agama. Kita juga akan mendengarkan propaganda agama lain yang tidak kita kehendaki. Tetapi kita juga menyadari, bahwa di TV banyak pula yang menayangkan program pengajian, ceramah, diskusi dan berita yang mengandung nilai positif bahkan juga agamis.Hanya saja, biasanya hal yang seronok porno, aneh, lucu justru lebih banyak memberi kesan dibandingkan dengan hal yang datar, serius dan penuh nilai etika atau agama.Adegan kekerasan lebih terkesan di benak anak-anak dibandingkan dengan petuah agama.

Lebih dari itu, tidak mustahil juga banyak hal dilakukan oleh masyarakat kita yang merasa bangga atau naik gengsinya jika mengikuti gaya hidup global. Untuk kalangan seperti ini globalisasi merupakan gaya hidup, yang berarti mentalitasnya sudah dirasuki gaya global tersebut. Dalam pengertian inilah gaya pergaulan menjadi ukuran. Pergaulan kelompok menengah, ABG, kelompok eksekutif, kelompok anak muda sukses, kolompok anak orang kaya dan masih banyak lagi contoh kelompok yang di bangun atas dasar gengsi semata.Biasanya kelompok itu mendefinisikan sendiri dalam aturan kemana mereka menonton, kemana harus jalan-jalan, kemana harus makan, kemana tempat yang layak dianggap untuk kongkow-kongkow, yang semua itu tidak terlepas dari pengaruh global.Ambil contoh warung kopi seperti starbuck, ini bukan sekedar rasa, namun mempunyai gengsi sendiri demikian pula termasuk merk model pakaian, mobil dan semacamnya.

Dalam pendefinisian itu, rasanya banyak ancaman budaya berupa kebebasan yang datang dari dunia sekuler yang umumnya dari Barat. Ketika kebebasan itu berlebihan, maka nilai dan norma budaya lokal dan nasional terlebih lagi nilai agama akan terasa terancam olehnya. Tentu kebebasan disini tidak dalam kaitan yang positif seperti kebebasan berfikir, kebebasan menyampaikan pendapat, demikian juga kritik sosial.Namun kebebasan yang mengarah kepada kebebasan lahiriyah, egoisme dan 
hedonisme.Akibat dari kebebasan inilah yang kemudian melahirkan penyakit sosial seperti kebebasan penyalahgunaan narkoba, kebebasan seks (free sex), kebebasan makan ataupun minum barang haram.Kebebasan negatif itu selalu menjadi akibat atau bahkan juga sebab dalam mendapatkan uang untuk memperolehnya.Ini terjadi terutama sekaii pada masyarakat yang terlalu mudah hanyut untuk berimitasi dengan globalisasi negatif.Jelas ini berbeda dengan masyarakat yang sudah mempunyai kesiapan mental untuk tidak mudah terjerumus pada hal-hal yang mereka tidak sukai.Toh, di negeri Barat sendiri disadari adanya ancaman terhadap nilai agama yang mereka peluk. Itu semua sebagai contoh terhadap apa-apa yang sudah diungkap sebagai pengaruh dari budaya negatif, baik dari budaya hollywood maupun budaya perpustakaan.

Tetapi globalisasi juga memberikan dampak positif. ${ }^{31}$ Globalisasi yang memberikan dampak positif seharusnya menjadi tantangan bagi bangsa Indonesia untuk mampu menyerapnya, terutama sekaii dengan hal-hal yang tidak mengalami benturan dengan budaya lokal atau nasional.Terutama sekali dengan nilai agama. Dengan kata lain, bagaimana agar nilai-nilai positif yang ada di Barat dapat masuk ke bangsa kita dan dapat pula dipraktikkan di tengah masyarakat kita seperti budaya disiplin, kebersihan, tanggungjawab, egalitarianisme, kompetisi, kerja keras, penghargaan terhadap waktu, penghargaan terhadap orang lain, terpanggil untuk membantu orang lain yang memang membutuhkan bantuan, demokratisasi dan semacamnya. Disinilah seharusnya agama mampu memberi bimbingan ke arah yang terang itu, yaitu meniru hal-hal yang positif dari Barat.Juga, bagaimana agama mampu menyaring yang baik dan dapat diikuti, dan yang jelek harus dihidari.

Menghadapi globalisasi yang merupakan kelanjutan dari modernisasi, Nurcholis Madjid ketika mengomentari modenisasi ia menyatakan bahwa hal itu merupakan keharusan dan tidak bisa dihindari, Islam sebenarnya sangat sesuai dengan modernisasi itu (Al-Qur'an, 7: 54; 25: 2, 32: 7; 40: 3; 10:101; 35:13). Begitu pula dengan kelanjutannya yaitu globalisasi. ${ }^{32}$

Umat masuk globalisasi berarti masuk arena kompetisi. ${ }^{33}$ Kompetisi dalam semua bidang kehidupan, hanya saja sering ditandai oleh konsumerisme.Ini

\footnotetext{
${ }^{31}$ Arif Furchan, Transformasi, hal. 40

${ }^{32}$ Muhammad Kamal Hasan, Modernisasi Indonesia-Respon Cendikiawan Muslim, (Jakarta: LSI, 1987), hal. 31

${ }^{33}$ Qodri Azizy, Melawan Globalisasi, (Jakarta: Pustaka Pelajar, 2003), hal. 26
} 
memerlukan landasan, sehingga mampu menjadi perisai diri menghadapi kompetisi konsumerisme dan mampu pula menghadapi kehidupan yang wajar bahkan juga sesuai dengan nilai-nilai budaya dan agama. Contoh yang ekstrem adalah adanya kebebasan berlebihan termasuk kebebasan seks dan kebebasan kehidupan negatif yang lain. Maka disini perisai mentalitas menjadi sangat penting.Dalam waktu yang bersamaan kompetisi juga berkaitan dengan kemampuan dan prestasi.Kalau sebelum globalisasi, kompetisi belum sangat mengemuka, maka pada era ini kompetisi sangat menonjol, bukan hanya taraf lokal tetapi juga taraf antar Negara. Kalau selama ini sebuah Negara akan dengan mudah membuat aturanmain sehingga dapat dijadikan perisai untuk mencegah serangan kompetisi dari luar, maka kini sudah tidak dapat lagi. Kalau dulu Sumber Daya Manusia (SDM) yang hebat dapat dibatasi kini tidak dapat lagi.Oleh karena itu, dalam menghadapi kompetisi seperti ini umat Islam perlu mempersiapkan diri.

Memrsiapkan mental dalam kompetisi dan dalam waktu yang bersamaan mempersiapkan kemampuan SDM sehingga mampu berkompetisi, ini akan meliputi segala aspek kehidupan dalam hal perdagangan, pelayanan atau jasa dan lainnya. Kompetisi juga membutuhkan rasa percaya diri (self confidence). ${ }^{34}$ Tentu saja sikap konfiden serta kaitannya dengan sikap individualisme (bukan egoisme). Oleh karena itu wajar kalau kehidupan di dunia Barat yang liberal meliputi sistem ekonomi dan pola hidup harus dilandasi kepribadian yang individuals, agar kita tidak terjebak ketika kita mengartikan individualisme, maka kita harus selalu ingat bahwa istilah ini tidak identik dengan egoisme dan selfness. Ketika seseorang harus berhadapan dengan dunia kompetisi, maka ia harus membuat fondasi yang kuat tentang self-confidence. Skill dan profesi apapun yang dimiliki seseorang tanpa fondasi self confidence tidak akan mampu berkompetisi. Untuk mewujudkan self confidence dalam berkompetisi, seseorang harus memenuhi dirinya sendiri denganbeberapa modal, bukan hanya perasaan saja.Di samping modal pengetahuan, modal mentalitas juga diperlukan.Etos kerja keras yang berorientasi pada prestasi, kedisiplinan, ketabahan tanpa mudah menyerah bahkan juga mentalitas kewirausahaan adalah hal-hal yang diperlukan dalam kerangka kompetisi dalam dunia perdagangan bebas.

\footnotetext{
${ }^{34}$ Qadri Azizy, Melawan, hal. 27
} 
Selain itu diperlukan pula beberapa landasan yakni landasan spiritual dengan keimanan, untuk menghindarkan seseorang dari kekosongan jiwa menghadapi kompetisi konsumerisme. Wujud prestasi berupa amal shaleh, hal ini diperoleh setelah melakukan kerja keras, kedisiplinan dan prestasi, kemudian berada pada kebenaran, artinya berada pada frame work, selalu mempunyai lansasan hukum yang kuat serta pelaksanaan hukum yang mapan. Perlunya chek and balance, saling mengkritik yang konstruktif dan saling memberi informasi dan saling mengingatkan.

Dalam era globalisasi, Islam harus memiliki peran besar, sebagaimana agama yang memberi petunjuk, (hudan) dan menegakkan 'amar makruf dan melarang yang munkar.Dengan landasan keimanannya Islam harus mampu memberi benteng, penangkal pengaruh budaya bebas yang kini menjadi keprihatinan para pemuka agama dan sekaligus juga mampu membuat screening dan mendukung serta memgembangkan budaya perpustakaan yang sesuai dengan ajaran Islam. Konsep benar dan salah tidak bisa lepas sama sekali dari kerangka Islam, dengan modal kajian Islam seperti yang disebutkan, maka Islam akan mampu bukan saja bertahan menghadapi globalisasi, namun juga sekaligus memberi arah atau ruh era ini.Akan semakin lengkap bila ajaran Islam yang dapat menjadi benteng globalisasi, jika umat Islam sendiri menujukkan prestasi dan kemampuannya dalam segala bidang, bukan saja bidang pemikiran agama dan menggambarkan moralitas utama tapi juga berprestasi dalam bidang ekonomi, pendidikan dan IPTEK serta dapat menjadi tauladan bagi dunia.

\section{Metodologi Pendidikan Islam}

Metode dalam bahasa arab adalah at-thariqah. ${ }^{35}$ Pendidikan Islam adalah pendidikan yang bersumber pada nilai-nilaiAl-quran dan Assunnah, juga ijtihad pemikir muslim. ${ }^{36}$ Pendidikan Islam pendidikan yang jenisnya beraneka ragam dan mengalami perkembangan sejak Indonesia mardeka dan tetap eksis hingga hari ini. Pendidikan Islam dari satu masa ke masa yang lain menghadapi berbagai tantangan, saat ini tantangannya semakin bertambah di era globalisasi. Globalisasi era dimana kehidupan manusia antara satu negara dengan negara lain hubungannya demikian mudah dan cepat, melalui internet, TV dengan mudah dalam hitungan detik melihat berbagai peritiwa perang, atau permainansepobbola di negara lain. Melalui hal itu orang dapat

\footnotetext{
${ }^{35}$ Abuddin Nata, Filsafat Pendidikan Islam, (Jakarta: Logos, 1999), hal. 92

${ }^{36}$ Abuddin, Filsafat, hal. 20
} 
pula disuguhi ekses porno yang dapat mempengaruhi nilai-nilai mulia kehidupan seseorang.

Manusia dari era hingga ke era global sekarang ini tetap sama sosoknya. Hanya dalam merespon siapa itu manusia, ilmuan barat berbeda dengan ilmuan Muslim.Ilmuan barat memandang manusia dengan ukuran materi atau dengan kedudukannya, tetapi ilmuan Muslim memandang manusia Muslim dari segi taqwanya.Manusia dalam pandangan ilmuan Islam adalah makhluk yang sangat sempurna diciptakan oleh Allah Subhanahuwata'ala. Mekipun manusia diciptakan dari sesuatu yang sangat hina, tetapi bila ia taqwa ia akan menjadi manusia yang mulia dibandingkan dengan penciptaaan Allah lainnya. Manusia dari perespektif ilmuan Barat, adalah manusia yang berasal dari seekor hewan yang bernama monyet atau melihat manusia ras lain hanyalah berupa seonggok daging yang bisa dibuat sewenang-wenang.Atau ilmuan Barat memandang hanya seonggok materi yang tiada bernilai.Oleh karena itu manusia barat berpandangan dalam hidupnyalebih kepada sisi meterialisme.

Muslim karena itu melihat manusia berbeda dengan pandangan Barat demikian pula dalam metode pendidikannya.Metode pendidikan Islam mempertimbangkan nilainilai agama yang dapat menjadi nilai nilai-nilai moral terhadap anak didik.Ramalius berpandangan bahwa metode pendidikan Islam harus merujuk kepada dua sumber yaitu al-quran dan Assunnah, Assunnah mempunyai dua fungsi yaitu untuk menjelaskan motode pendidikan Islam yang belum jelas dalam alquranserta metode pendidikan yang dilakukan Rasululllah dalam kehidupan sehari-hari serta cara beliau menanamkan nilainilai keimanan kepada pengikutnya. ${ }^{37}$

Ada bebarapa prinsip dasar yang melandasinya, pertama prinsip dasar biologis, ini mempunyai pengaruh dalam perkembangan intelektual manusia dengan semakin lama perkembangan inteketualnyaakansemakinberkembangdemikian pula ada pengaruh terhadap perbedaan secara biologis terhadap seseorang yang mnenderita kelainan tidak sama dengan orang yang normal. ${ }^{38}$ Prinsip dasar lain adalah mempertimbangkan dasar psikologis anak didik yang sangat besar pengaruhnya terhadap internalisasi nilai dan transformasi ilmu. ${ }^{39}$ Kemudian dasar sosiologis, dimanatenaga pengajar dalam

\footnotetext{
${ }^{37}$ Ramayulis, ilmu pendidikan Islam, (Jakarta: Kalam Mulia, 2004), hal. 158

${ }^{38}$ Suyudi, Pendidikan Dalam Prespektif Al-quran :Al-quran Integrasi Epistemology, Bayani, Burhani dan Irfani, (Yogyakarta: Mikhraj, 2005), hal. 58

${ }^{39}$ Ramayulis, Ilmu pendidikan islam, hal. 158.
} 
berkomunikasi dengan anak didik, ada pengaruh timbal baliknya yang bisa berakibat positif bisa berakibat negatif. ${ }^{40}$

Lalu ada beberapa hal yang harus dipertimbangkan pula dalam melaksanakan metode pendidikan Islam.Abuddin Nata berpandangan, pertama, pendidikan Islam yaitu mempermudah, bukan mempersulit, pelaksanaanya dengan metode yang sederhana, manusia sangat senang dengan yang simpel tidak bertele-tele. ${ }^{41}$ Kedua, adanya kesinambungan, sequen dan sistematis, dari satu pengertian ke pengertian berikutnya serta fleksibel dan dinamis. ${ }^{42}$

Dalam penerapan metode pendidikan Islam yang juga harus dipertimbangkan tentangposisi manusia dalam sistem sosial, betapapun rendah posisinya dalam kehidupan ia tetap harus dihargai. Metodologi ini melihat posisi seseorang bukan pada tempatnya dimana ia berada tetapi dilihat dari kesetaraan manusia di mata SangKhaliq. Posisi ini bisa dimiliki oleh siapa saja termasuk manusia yang sedang diajar oleh tenaga pengajar.Di samping itu tenaga pengajar adalahjuga manusia biasa yang memiliki banyak kelemahan (do'if), betapapun ia memiliki tingkat keilmuan yangtentu sangat relatif. Metodologi pendidikan Islam ini melihat bahwa manusia yang di depannya bukan seperti tong kosong tetapi ia juga memiliki potensi dan memiliki harkat dan martabat.Manusia dari kacamata kejiwaan berapapun umurnya, masih kecil,remaja dan dewasa senang dihargai dan senang dimanusiakan.Kepada siapapun firman Allah menggmbarkanyang berbunyi: Fabima rahmatin minallah lintalhum walau kunta fadzzan ghalibal qhalibalqalbi lanfaddu minhaulik, artinya: "maka disebabkan rahmat Allah-lah kamu berlaku lemah lembut terhadap mereka (anak didik) sekiranya kamu bersikap keras lagi kasar tentulah mereka akan jauh hatinya dari dirimu (QS. ali. Imran, 159), dan dalam ayat yang lain berbunyi, ud'u ila sabili rabbika bil-hikmah walmau'izhah al-hasanah wajadilhum billati hiya ahsan, artinya: "ajaklah anak didik ke jalan Tuhanmu dengan hikmah dan pelajaran yang baik dan diskusilah dengan mereka dengan cara yang baik (QS. al-Nahl, 125).

\footnotetext{
${ }^{40}$ Zakiyah Derajat, dkk. Metode Khusus Pengajaran Agama Islam,(Jakarta:Bumi Aksara, 1995), hal. 140.

${ }^{41}$ Abuddin Nata, Abuddin Nata, Manajemen Pendidikan, Mengatasi Kelemahan Pendidikan Islam Di Indonesia (Jakarta:Praneda Media, 2003), hal. 275.

${ }^{42}$ Ramayulis, Ilmu Pendidikanislam, hal. 163
} 


\section{Kesimpulan}

Pendidikan Islam saat ini hidup di era globalisasi, fenomenanya hal yang nyata di tanah air.Fenomenalogi-fenomena tengah dihadapi sepertikemajuan ilmudan teknologi memberikan hal yang positif,juga berakibat negatif yang harus menjadi perhatian pendidikan Islam.Institusi ini harus tampil membenahi dirinya memulai pendidikan yang membentuk anak didik yang memiliki kreatifitas,berpengetahuan agama juga berpengetahuan umum, serta memberikan skill kepada anak didik.Karena hal-hal itulah yang menjadi prasyarat dalam kehidupannya, apalagi di era glaobalisasi sekarang.

Produk pendidikan Islamtidak dapat mengelak dari penetrasi budaya global. Era ini telah melahirkan budaya ala Barat yang mendahulukan sisi materialistik dan hedonistik, penetrasinya melalui TV, internet dan media lainnya ini akan melemahkan budaya positif yang ada. Budaya tersebut harus dihadapi dengan wawasan ilmu yang luas serta diperlukan jiwa besar dan penuh kesabaran, dan menghindari tindakantindakan $a$-budaya (tidak berbudaya). Ada budaya positif sepertimemiliki etos ilmu, etos kerja, disiplin, bersih, jujur harus direspon secara positif, karena inilah juga nilainilai Islam yang sering kita lupakan. Untuk itu, membangun pendidikan sangat perlu dilakukan.Pendidikan bukan saja menanamkan ajaran Islam yang bersifat ritual tetapi memerlukan penguasaan sains dan teknologi serta skill.Metodologi pendidikan sangat penting pula dalam proses pendidikan.Al-qurandan Assunnah yang menjadi pedoman dalam proses pendidikan Islam menempatkan manusia pada tempat terhormat dan juga harus diperlakukan secara terhormat. Berangkat dari fisolsof itu metodologi pendidikan harus diterapkan.Metode yang memanusiakan manusia, metode yang membuat psikologis anak didiknya nyaman ketika menerima pelajaran.Melalui proses ini akan dicapai tujuan pendidikan yang diinginkan.[]

\section{Daftar Pustaka}

Azra, Azyumardi, Esai-esai Intelektual Muslim dan Pendidikan Islam, Jakarta: Logos, 1998

Azra, Azyumardi, "Upaya IAIN Menjawab Tantangan Zaman”, Perta, Vol. V/ No. $01 / 2001$

Arifin, Syamsul, "Strategi Pendidikan Dalam Rangka Menghadapi Globalisasi", Tarbiya, UIN Syarif Hidayatullah Jakarta, Vo. 2 Des 2014
S,Akbarand
Hastings
Donnan,
Islam Globalization
and Postmodernity,London:Routledge, 1994 
Amir, Yasraf Piliang, Dunia Yang Dilipat, Bandung: Mizan, 1998

Alim, Sahirul, Menguak Keterpaduan Sains, Teknologi dan Islam, Yogyakarta: Dinamika, 1996

Al-Naquib al-Attas, Syed Muhammad, Konsep Pendidikan Dalam Islam, Bandung: Mizan, 1994

Azizy, Qodri, Melawan Globalisasi, Jakarta: Pustaka Pelajar, 2003

Baskoro, Aryo,."Tantangan dan Peluang.....Center for Risk Management studies Indonesia, diunduh tanggal 3 Oktober 2015

Dofier, Zamakhsjari, Tradisi Pesantren, Jakarta: LP3ES, 1994

Derajat, Zakiyah, dkk. Metode Khusus Pengajaran Agama Islam, Jakarta:Bumi Aksara, 1995

Furchan, Arif, Transformasi Pendidikan Islam di Indonesia, Yogyakarta: Gama Media, 2006

Indra, Hasbi, "Pesantren dan Peradaban”,Jabal Hikmah, STAIN Jayapura, Vol. 2. No. 4 Juli 2009

--------------, "Manajemen Pendidikan Islam", Tawazun, Pascasarjana Univ. Ibn Khaldun, Vol. 4 No. 4-Juli 2010

Irfani, Fahmi. Potret Pendidikan Islam Padam Masa Klasik (Dinasti Abbasiyah dan Ummayah) Jurnal Fikrah, Volume 7 No 1, 2016

Kamal Hasan, Muhammad, Modernisasi Indonesia-Respon Cendikiawan Muslim, Jakarta: LSI, 1987

Mas'ud, Abdurrahman Mas'ud, "Pendidikan Islam dalam Era Reformasi dan Globalisasi”, Religia, STAIN Pekalongan, Edisi II/ 2006

Nata, Abuddin, Filsafat Pendidikan Islam, Jakarta: Logos, 1999

,Manajemen Pendidikan, Mengatasi Kelemahan Pendidikan Islam Di IndonesiaJakarta:Praneda Media, 2003

Nasution, Harun, Islam Rasional, Bandung: Mizan, 1989

Peraturan Pemerintah No. 55 tahun 2007.

Pontren, Dit. PD., Pola pembinaan TKQ/TPQ,Jakarta: Dit. PD. Pontren, 2013

Pontren, Dit.PD.,Pedoman kurikulum TKQ/TPQ, Jakarta: Dit. PD. Pontren, 2013

Pontren, Dit. PD.,Pola Pengembangan Madrasah Diniyah, Jakarta: Dit. PD. Pontren, 2007

Pendis, Ditjen, Statistik Pendidikan Islam, 2012-2013

Rasyad, Aminuddin, Majalah Ikhlas, Depag, No. 22 tahun 16, 2002

Ramayulis, ilmu pendidikan Islam, Jakarta: Kalam Mulia, 2004

Saridjo, Marwan, Pendidikan Islam Dari Masa ke Masa, Jakarta: Penamadani, 2010

Suyudi, Pendidikan Dalam Prespektif Al-quran :Al-quran Integrasi Epistemology, Bayani, Burhani dan Irfani, Yogyakarta: Mikhraj, 2005 